\title{
Food- and Water- Intake, Urinary and Fecal Output, and Urinalysis in the Wild-originated Cynomolgus Monkeys (Macaca fascicularis) under the Indoor Individually-caged Conditions
}

\author{
Michihiro T. SUZUKI, Masaaki HAMANO, Fumiaki CHO*, and Shigeo HONJO* \\ The Corporation for Production and Research of Laboratory Primates., and \\ ${ }^{*}$ Tsukuba Primate Center for Medical Science, The National Institute \\ of Health., Hachimandai, Tsukuba-shi, Ibaraki-ken, 305.
}

(Received 11 March 1988/Accepted 22 July 1988)

\begin{abstract}
Daily food- and water-intake, and urinary and fecal output were determined with 253 wild-originated cynomolgus monkeys kept in individual cage. In addition, urinalysis was done for freshly collected urine. A statistically significant correlation was observed between total water intake and urinary output as well as between urinary output and urinary specific gravity $(\mathrm{p}<0.01)$.
\end{abstract}

野生由来成熟カニクイザルの飼料摂取量, 飲水量, 粪量, 尿量 扣よび尿の一般性状について 鈴木通弘・浜野政章・長 文昭*・本庄重男*

一般に動物の 1 日当りの飼料拱取量, 飲水量, 䔬量, および尿量等を知っておくことは，飼育管理を的確にし てゆく上で必要なことである。しかし，サル類に関し， 多数の動物を用いてそれらの調査をおこなった報告は少 ない $[1,2,5]$.

そこで，私どもは，筑波医学実験用霊長類センター [3]に怙いて個別ケージで飼育管理されている野生由来 健康成熟カニクイザルの 1 日当りの飼料摂取量, 飲水 量, 筫量および尿量, ならびに尿の一般性状につき調査 したので，その結果を記載する。

対象とした動物は東南アジアより輸入後 $2-4$ 年経過 し，当施設の環境に馴化している成熟カニクイザルの雄 61頭（体重4.8-11.0kg），雌192頭（体重2.0-7.5 kg）で ある。飼育環境条件については，すでに報告 [3]した通
りである。測定の手順は以下の通りである。まず，午前 10時に採尿器（Fig. 1) をケージと污物受け架台との 間に取り付け（Fig. 2,3），その後30分以内に排泄され た尿の一般性状を尿比重計（血清蛋白屈折計, アタゴ社 製）と尿検査試験紙(マルティスティックス, マイルス・ 三共社製）を用いて検查した。次いで，午前11時に短冊 状に切ったリンゴとミカンを各 $100 \mathrm{~g}$ 与光, 給水瓶（容 量 $700 \mathrm{ml}$ ）により給水した。さらに午後 2 時にサル用 固形飼料（A B 型，オリエンタル酵母釈製）を $80 \mathrm{~g}$ 給与 した。翌日の午前10時に飼料と水の残量を測定し，それ ぞれの給与量から残量を差引いた值を摂取量とした。ま た，同時刻に污物受け架台上の採尿器に排泄されている 翼・尿を採取し直接秤量した。また，摂取されたりン ゴ, ミカンと固形飼料の水分含量と飲水量とを合計した 


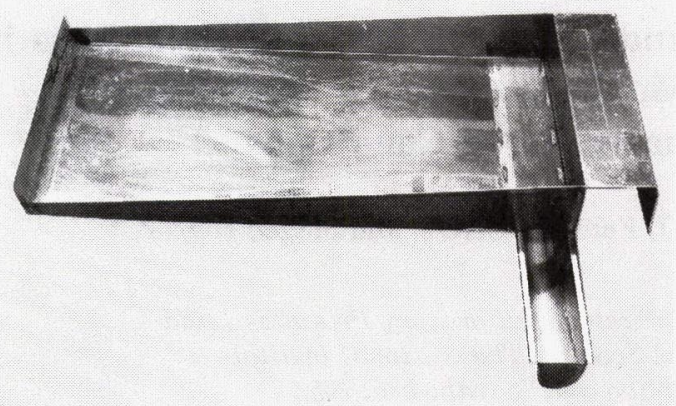

Fig. 1. The pan for collecting urine samples



Fig. 2. A step of procedure for setting up the pan on the base of cage rack

值を摂水量として別に示した。この場合, 食品成分表 [4] に基き,リンゴとミカンそれぞれ $100 \mathrm{~g}$ あたりの水 分量は $86 \mathrm{~g}, 89 \mathrm{~g}$ として計算した。固形飼料 $100 \mathrm{~g}$ あた りの水分量は $7 \mathrm{~g}$ として計算した。

Table 1 亿野生由来健康成熟カニクイザルの 1 日当 りの飼料摂取量の絶対值および飲水量, 排筫量, 排尿 量, 摂水量の絶対値, 体重 $1 \mathrm{~kg}$ 当りの值とそれぞれの 最小・最大值を示した。すなわち，固形飼料の摂取量は 雄で平均 $46 \mathrm{~g}$, 雌で平均 $31 \mathrm{~g}$ だった。リンゴの摂取量は 雌雄ともに平均 $96 \mathrm{~g}$, ミカンの摂取量は雌雄ともに平均 $87 \mathrm{~g}$, 飲水量は雄で平均 $311 \mathrm{ml}(50 \mathrm{ml} / \mathrm{kg})$, 雌で平均 $162 \mathrm{ml}(49 \mathrm{ml} / \mathrm{kg})$ であり, 摂水量は雄で平均 $474 \mathrm{ml}(76$ $\mathrm{ml} / \mathrm{kg})$, 雌で平均 $327 \mathrm{ml}(100 \mathrm{ml} / \mathrm{kg})$ と算出された。 尿量は雄で平均 $131 \mathrm{ml}(21 \mathrm{ml} / \mathrm{kg})$, 雌で平均 $89 \mathrm{ml}(27$

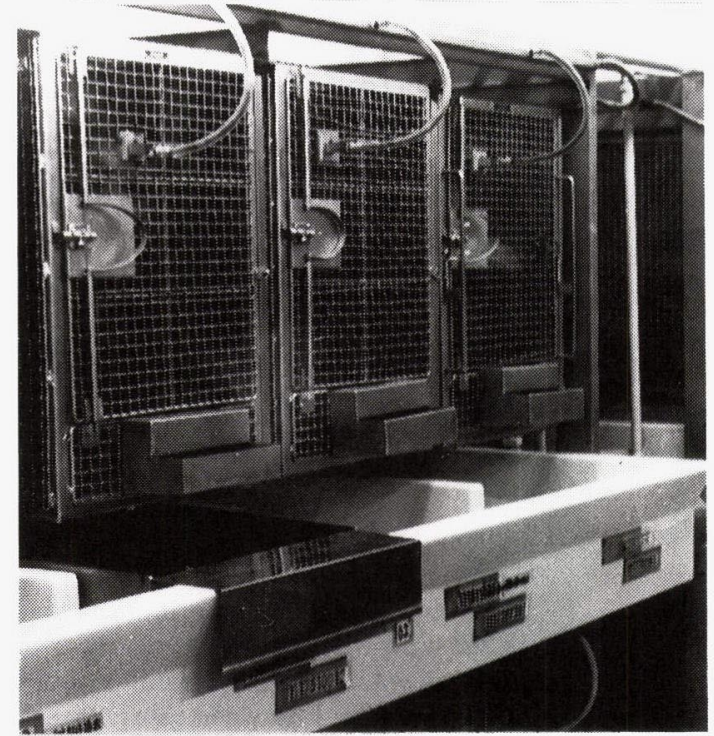

Fig. 3. Completion of setting up the pan

$\mathrm{ml} / \mathrm{kg})$, 排粪量は雄で平均 $19 \mathrm{~g}(3.0 \mathrm{~g} / \mathrm{kg})$, 雌で平均 $13 \mathrm{~g}(3.9 \mathrm{~g} / \mathrm{kg})$ であった。

尿の一般性状中, 尿比重については雌雄共に 1.003 1.039までのひろがりを持ち，1.006-1.010の範囲の值を 示した例が最も多かった（Fig. 4)。尿の $\mathrm{pH}$ につて は, 雄で 7-9, 雌 6-9のひろがりを認め, 雌雄共に $\mathrm{pH} 8$ の値を示した例が最も多かった（Fig. 5 ）。尿タ ンパクについては, 雌雄共に士を示した例が最も多かっ た（Fig. 6)。ブドウ糖, ケトン体, ビリルビン, 潜 血, 亜硝酸塩, ウロビリノーゲンについては雌雄とも全 例陰性であった。摂水量と尿量の関係を調べた結果, 雌 雄共に摂水量が増加すると尿量も増加する傾向が認めら れた（ $\mathrm{r}=0.52$ および $0.54 ， \mathrm{p}<0.01)$ 。尿量と尿比重 の関係については, 雌雄共に尿量が多くなると尿比重が 低下する傾向が認められた（ $r=0.58$ おび $0.45, p<$ 0.01)。

動物を実験室内にて飼育し,さらに繁殖し継代してゆ くためには,その動物の生物学的特性についてできるだ け多くの, 且つ正確な情報を得て扣くことが必要であ る。本短報に記載した調査項目は, 我々が既に報告して いる血液諸性状 $[8,9]$ あるいは眼底所見 $[6,7]$ 等と同 様に, 動物を飼育管理していく上で是非知っておくべき 項目である。にもかかわらず，この種の報告は余り見当 らない。従来の報告を通覧するに, Heywood は, アカ ゲザル28頭, バブーン60頭およびカニクイザル44頭を用 い, 尿量, 尿 $\mathrm{pH}$ および尿比重の平均值を求め, アカゲ 
Table 1. Food- and water- intake, urinary and fecal output per day in cynomolgus monkey

\begin{tabular}{|c|c|c|c|c|c|c|c|}
\hline & Male & & & & Female & & \\
\hline Number of animals examined & 61 & & & & 192 & & \\
\hline Body weight & $6.5 \pm 1.3^{*}$ & & & & $3.4 \pm 0.9$ & & \\
\hline Commercial monkey chow $\mathrm{g}$ & $46 \pm 23$ & & & & $31 \pm 17$ & & \\
\hline Apple & $96 \pm 11$ & & & & $96 \pm 13$ & & \\
\hline Orange & $87 \pm 19$ & & & & $87 \pm 17$ & & \\
\hline Drinking water intake $\mathrm{ml}(\mathrm{ml} / \mathrm{kg})$ & $311 \pm 187$ & $30-830^{* *}$ & $(50 \pm 33)$ & $(4-126)$ & $162 \pm 153$ & $10-1070 \quad(49 \pm 48)$ & $(3-406)$ \\
\hline Total water intake ${ }^{* * *} \mathrm{ml}(\mathrm{ml} / \mathrm{kg})$ & $474 \pm 187$ & $207-947$ & $(76 \pm 35)$ & $(25-156)$ & $327 \pm 155$ & $144-1249(100 \pm 51)$ & $(30-474)$ \\
\hline Fecal output $\quad \mathrm{g}(\mathrm{g} / \mathrm{kg})$ & $19 \pm 8$ & 2-43 & $(3.0 \pm 1.3)$ & $(1-6)$ & $13 \pm 7$ & $1.44 \quad(3.9 \pm 2.3)$ & $(1-18)$ \\
\hline Urinary output & $131 \pm 81$ & $17-376$ & $(21 \pm 15)$ & $(3-72)$ & $89 \pm 59$ & $(27 \pm 18)$ & $(3-139)$ \\
\hline
\end{tabular}

$*$ : Mean \pm standard deviation $\quad * *$ : Minimum - Maximum $\quad * * *$ : Drinking water plus water in food (apple, orange and monkey chow) taken

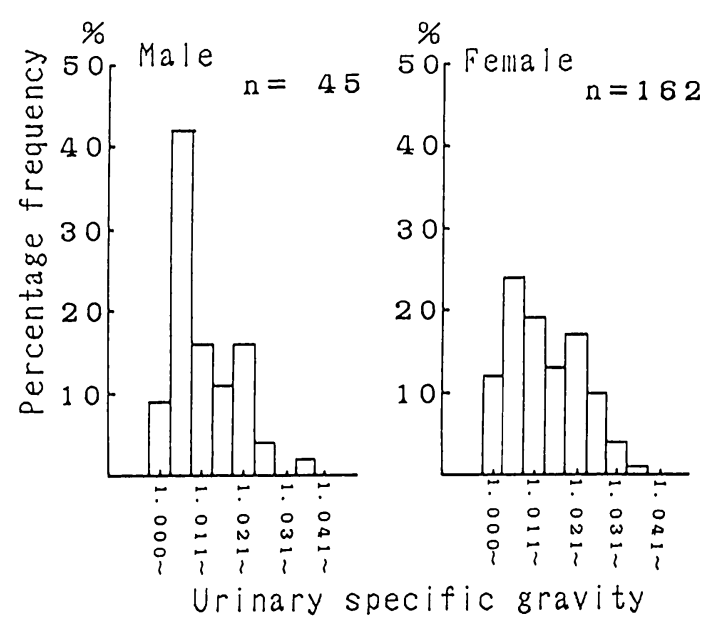

Fig. 4. Frequency distribution of urinary specific gravity
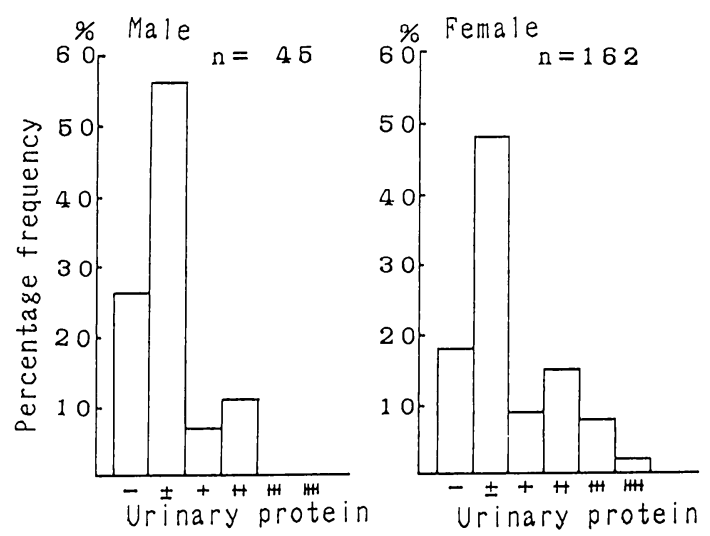

Fig. 6. Frequency distribution of urinary protein

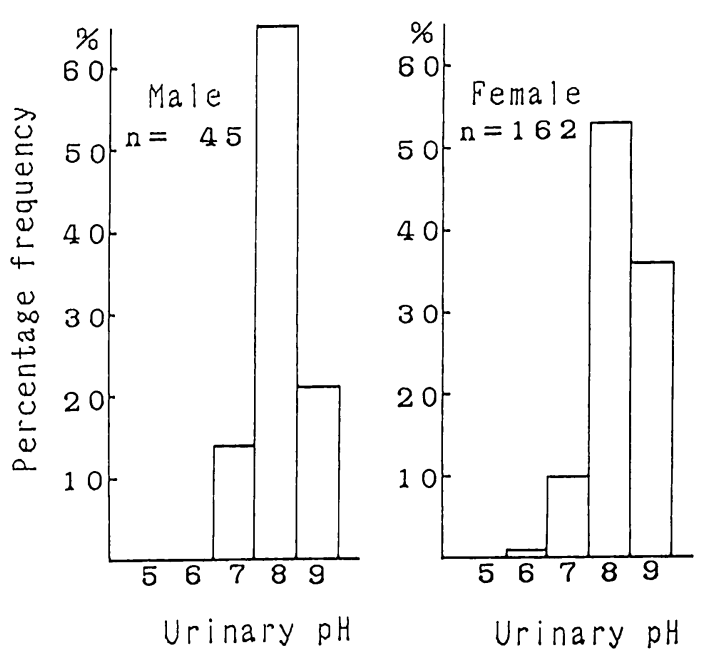

Fig. 5. Frequency distribution of urinary $\mathrm{pH}$

ザルではそれぞれ $35 \mathrm{ml}, 8.2 ， 1.028$ ，バブーンではそれ ぞれ $52 \mathrm{ml}, 7.9,1.031$ およびカニクイザルではそれぞ れ39ml，8.4，1.025であったと報告している [1]。また 本庄らは, カニクイザルの 1 日の尿量を調ベ，およそ50 $-400 \mathrm{ml}$ と非常に幅があると, 記載している [2]。また, 及川らは, アカゲザルの雄10頭, カニクイザルの雄22頭, 雌20頭で领水量, 尿量, 摂水量, 尿 $\mathrm{pH}$ および尿比重を 調べた結果, アカゲザルとカニクイザルの飲水量は個体 間の変動が激しく，20-30\%の個体で多量に飲水するも のが認められたとし, 通常量を飲水する個体と多量に飲 水する個体とを分けて, 飲水量, 尿量, 恸取量等を報告 している。すなわち, 摂水量, 飲水量, 尿量を体重 $1 \mathrm{~kg}$ 当りの日量で表し，アカゲザル雄の通常量飲水個体では それぞれ88,74, 67ml, 多量に飲水する個体ではそれぞ 
れ199，183，178ml, カニクイザル雄の通常量飲水個体 ではそれぞれ81，55，48ml,多量に飲水する個体ではそ れぞれ164，141，122ml，カニクイザル䧳の通常量领水 個体ではそれぞれ $67 ， 37 ， 33 \mathrm{ml}$,多量に领水する個体で はそれぞれ156，123，102mlであったとしている。さ らに，尿中 $\mathrm{pH}$ にいては6.7-8.3であったとしている [5]。今回の調査結果と Heywood, 本庄, 及川らの成 績との間には羑を認めた。すなわち, Heywood の成績 における尿量は我々のそれの1/2-1/3の值であった。し かし, 我々の尿量の最小值 $10 \mathrm{ml}$, 本庄らの尿量の最小値 $50 \mathrm{ml}$ から考兵ると, 彼らの使用した個体は排尿量の少 ない個体であったことも考学られる。いずれにしても彼 らの報告に飼育あるいは測定条件の詳細な記述がないた め, これ以上推定し議論することはできない。なお，本 庄らが示した尿量の値と今回の成績とはほぼ一致した。

一方, 及川らの尿量の值は雙については我々の成績とほ とんど同じであったが, 雄については体重 $1 \mathrm{~kg}$ 当りで 約 2 倍量の排尿がみられている。逆に，摂水量について は雄ではほぼ同様の值であったが, 雌では体重 $1 \mathrm{~kg}$ 当 りで約30\%ほど低い值を示している。しかし互いの飼育 条件が異なることから,この程度の差の生ずることは充 分考えられる。なお，本報告の提䬣量からカニクイザル の 1 日摂取総カロリーを概算すると倠で $205 \mathrm{kcal}$, 雄で $263 \mathrm{kcal}$, となる。これは, 体重 $1 \mathrm{~kg}$ 当りに換算してそ れぞれ60kcal, 40 kcal である。

今後, 血液性状 $[8,9]$ や眼底所見 $[6,7]$ の調査で示 したよらな, 年龄に伴ら変化や妊娠中, 哺育中あるいは 1 歳齢以下の個体での成績についても報告したい。さら に, 疾患, たとえば糖尿病のサルにおけるこの種の検討 を行らことも必要である。今回の調査により, 野生由来 健康成熟カニクイザルの 1 日の䣏量, 尿量および摂水,
および摄䬣量等極く基礎的な数值を知ることができた。 これらの数値は実験動物施設における1 日当りの動物系 の污物総量を概算する上での資料ともなり得よう。

\section{要 約}

東南アジアより輸入後 $2-4$ 年経過し, 施設の環境に よく馴化した成熟カニクイザルの雄61頭, 雌 192 頭を対 象とし, 1 日当りの飼料摂取量, 飲水量, 翼量, 尿量お よび尿の一般性状について調査した。また, 摂水量と尿 量との間および尿量と尿比重との間の相関関係を検討し たところ, 前者では正の, 後者では負の相関性が認めら れた。

\section{文嶰}

[1] Heywood, R. (1972). In Med. Primatology 1972, pp 95-99, Goldsmith, E. and Moor-Jankowski, J. (edit.), S. Karger-Basel, New York.

［2］本庄重男・長 文昭・藤原 徹・高阪精夫（1975）実験 動物テキストXIV 各論サル類, pp 38, 日本実験動物研 究会教育部会編，日本実験動物研究会.

[3] Honjo, S. (1985). J. Med. Primatol. 14, 75-89.

[4]科学技術庁資源調查会編 (1981) 常用量目安栄着価早見 表, pp 140，150，中島泰子・安東明夫・折田義正編集， 医歯薬出版株式会社, 東京.

［5] 及川 弘・山下武夫・武藤通彦・沢井守治(1982)．実験 動物, 31, 279-286.

［6] 鈴木通弘・成田勇人・長 文昭・本庄重男(1983)，比較 眼科, 2, 21-26.

［7]鈴木通弘・成田勇人・田中吉春 - 長 文昭 - 福井正信 (1984)．実験動物，33，173-180.

[8] Yoshida, T. (1981). Japan J. Med. Sci. Biol. 34, 239242.

［9］吉田高志・鈴木絹江・長 文昭・本庄重男(1986). 実験 動物, 35, 329-338. 